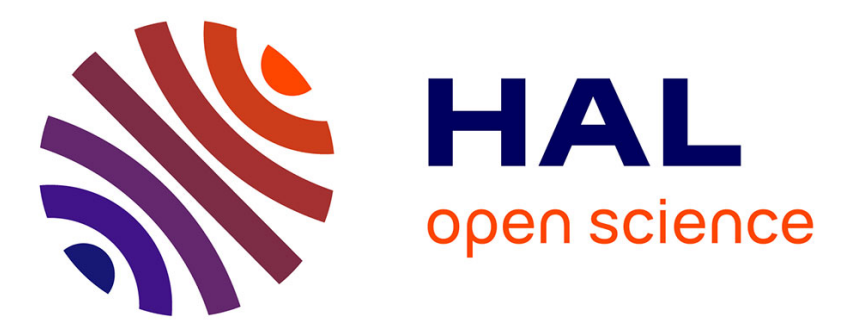

\title{
Tintin's travel traumas: Health issues affecting the intrepid globetrotter
}

Eric Caumes, Loïc Epelboin, France Leturcq, Phyllis Kozarsky, Peter Clarke

\section{To cite this version:}

Eric Caumes, Loïc Epelboin, France Leturcq, Phyllis Kozarsky, Peter Clarke. Tintin's travel traumas: Health issues affecting the intrepid globetrotter. La Presse Médicale, 2015, 44 (6, Part 1), pp.e203e210. 10.1016/j.lpm.2015.01.006 . hal-01153737

\section{HAL Id: hal-01153737 \\ https://hal.sorbonne-universite.fr/hal-01153737}

Submitted on 20 May 2015

HAL is a multi-disciplinary open access archive for the deposit and dissemination of scientific research documents, whether they are published or not. The documents may come from teaching and research institutions in France or abroad, or from public or private research centers.
L'archive ouverte pluridisciplinaire HAL, est destinée au dépôt et à la diffusion de documents scientifiques de niveau recherche, publiés ou non, émanant des établissements d'enseignement et de recherche français ou étrangers, des laboratoires publics ou privés. 


\section{Tintin's travel traumas: Health issues affecting the intrepid globetrotter}

Les problèmes de santé de Tintin: plus de traumatismes que de pathologies du voyageur

Eric Caumes (1), Loïc Epelboin (1), France Leturcq (2), Phyllis Kozarsky (3), Peter Clarke (4)

1) Department of Infectious and Tropical Diseases. Groupe Hospitalier Pitié-Salpêtrière. 45-

83 Bld de l'hôpital, 75013 Paris. University Pierre et Marie Curie. Paris, France

2) Laboratoire de Génétique moléculaire , Hôpital Cochin , 75014 Paris UPMC -Inserm

UMRS 974 Paris France

3) Emory University, Department of Medicine, Division of Infectious Diseases, Atlanta, GA

4) Manx Text: 118 Woodbourne Road, Douglas, Isle of Man IM2 3BA, British Isles

Correspondence: Eric Caumes Department of Infectious and Tropical Diseases. Groupe Hospitalier Pitié-Salpêtrière. 45-83 Bld de l'hôpital, 75013 Paris, France.

Email: eric.caumes@psl.aphp.fr

Tel : 0033142160114

Key Words: Tintin, Hergé, Snowy, concussion, trauma, accidents.

Words number (text): 284 words; 1566 signs

Words number (summary): 2858 words, 15579 signs 


\section{Summary}

Background. Despite the highly hazardous life-style led by comic book characters such as Tintin, we are unaware of any previous systematic description of the challenges and health impairments faced by Tintin in the course of his adventures.

Methods. We evaluated the spectrum of health impairments (HIs) that Tintin sustained in his 23 adventures as well as their causes, consequences, and relation to travel. We diagnosed Tintin's HIs according to descriptive terms in the text. We then classified HIs as traumatic and non-traumatic, and distinguished between intentional (those perpetrated by others) and unintentional events.

Results. We found 236 events leading to 244 HIs, 13 kidnappings, six hospitalisations and two surgical procedures. There was a median of eight HIs/adventure (range 1-30/adventure). The mean number of HIs per adventure was much greater before 1945 than subsequently (14.9 v 6.1; p 0.002), which was also true of the number of kidnappings (11 v 2; p 0.001). Of the 244 HIs, there were 191 cases of trauma (78.3\%) and 53 non-traumatic problems $(21.7 \%)$. The most common form of trauma was concussion (62\%), whereas the most common forms of non-traumatic problems were sleep problems (15.1\%), depression/anxiety (13\%), and gas or chloroform poisoning (13\%). Overall, we found 46 losses of consciousness (LoC), including 29 traumatic and 17 non-traumatic LoCs. Of the 236 events, there were 69 (29\%) perpetrated by others against Tintin (including 55 homicide attempts), and 167 (71\%) events that were not (including 69 events related to Tintin's actions).

Conclusion. Tintin's almost superhuman qualities, a luxury afforded him by his fictional status, make him highly resistant to trauma. He is also not susceptible to the usual travelrelated illnesses but is easily influenced by his friends and Snowy, his faithful hound.

\section{Résumé.}

Interet. Malgré la vie hasardeuse menée par les héros de bandes dessinées comme Tintin, nous n'avons pas connaissance d'études ayant évalué les événements et les problèmes de santé présentés par Tintin pendant ses aventures.

Methodes. Nous avons évalué le spectre des problèmes de santé (PS) que Tintin a présenté au cours de ses 23 Aventures, ainsi que leurs causes, conséquences et lien avec le voyage. Les PS ont été diagnostiqués en fonction de leur description dans le texte puis classés en distinguant les problèmes traumatiques des problèmes non traumatiques. Les causes ont été classées en distinguant les événements intentionnels et non intentionnels. 
Resultats. Nous avons trouvé 236 evénements conduisant à 244 PS, 13 kidnappings, six

\section{Introduction}

Tintin is the eponymous hero of the Adventures of Tintin, a series created in 1929 by Georges Prosper Rémi (better known as 'Hergé'), a Belgian cartoonist (figure 1). Twenty-three Tintin adventures appeared between 1930 (Tintin in the Land of the Soviets) and 1976 (Tintin and the Picaros). Tintin is a boy reporter, explorer, investigator, and traveller [1, 2]. These swashbuckling roles understandably exposed him to a wide range of health impairments (HIs). 
Surprisingly, HIs have only rarely been described even for popular comic book characters two research articles [3, 4], and one editorial [5]. The Cyr family from Canada (aged five, seven, and 33) identified 50 losses of consciousness (LoC) in 16 of the 23 Tintin adventures [3]. We should note that pictures of Tintin apparently suffering LoCs were identified by the two Cyr children (whose average age was six), which suggests the LoCs in Tintin should be evaluated by a physician. Medrano et al also analysed appearances of, or allusions to, mental illness in the Tintin series but only to see how psychologically-impaired characters were portrayed [4]. Therefore the entire spectrum of HIs in Tintin's adventures remained to be examined.

Only two of Tintin's adventures, The Castafiore Emeralds and The Secret of the Unicorn, occurred entirely in his native Belgium $[1,2]$. In all other adventures, Tintin's home, initially Brussels and later Marlinspike Hall ("Chateau de Moulinsart", in French), was merely his launch pad or landing strip for each overseas odyssey. Tintin's voyages ultimately took him to a total of 23 real and fictional countries, not forgetting the moon and a meteorite. Tintin's travels regularly took him to hostile environments, whether the high seas (e.g. the Red Sea, Caribbean, and Arctic Ocean), deserts (the Sahara and Arabian Deserts), forests (the Amazon and Indonesian rain forests), or mountains (Himalayas and Andes). He took every conceivable means of transport: spaceships, planes, ocean-liners, all manner of boats, cars, motorbikes (figure 1), bicycles, trains (figure 2), horses, elephants, yaks and donkeys. Amazingly, although Tintin was exposed to a plethora of travel-related health hazards, they have never previously been characterized.

We assessed the full spectrum of HIs revealed in Tintin's adventures and their causes, consequences, and relation to travel.

\section{Methods}

We scrutinised all 23 completed volumes of Tintin's adventures. Focussing on Tintin, the protagonist, we assessed all the HIs that arose throughout his stays in Belgium and during his travels to tropical and non-tropical countries.

Tintin travelled to four of the world's five inhabited continents, visiting 23 countries plus the moon and a meteorite. We distinguished tropical from non-tropical countries using geographic and climatic criteria. Among the 18 real countries Tintin visited, eight are tropical and ten non-tropical (Table I). Tintin also visited five fictitious countries. We classified Borduria and Syldavia as non-tropical, and Khemed, Nuevo Rico and San Theodoros as tropical countries, totalling 11 tropical and 12 non-tropical countries. The only destinations 
most readers could not expect to visit, space, the moon (Explorers on the Moon), and a meteorite (The Shooting Star), were classified as 'undetermined'.

We diagnosed the types of HI according to the clinical description of Tintin, or his response, in the frames of the strip where each new HI occurred, and in the subsequent frames that often amplified the medical nature of the event. We primarily distinguished traumatic and nontraumatic HIs. We classified HIs as BTwCs (Body trauma without consequences other than pain), visible injuries (bumps, scratches and burns), concussion, loss of consciousness (LoC), and any other major HIs acknowledged by Tintin or the authors. BTwCs other than pain were defined by symbols revolving around Tintin's body (except his head) following a significant trauma without further visible consequences. 'Concussion' was defined as any head traumatic lesion and was termed 'grade I' (stars spinning round Tintin's head), 'grade II' (squiggles, candles, bolts of lightning surrounding his head), 'grade III' (LoCs lasting no more than one frame), and 'grade IV' (LoCs lasting at least two frames). LoCs included traumatic LoCs (TLoCs) (i.e. grade III and IV concussion, and asphyxia), and non-traumatic LoCs (NTLoCs) (LoCs from non-traumatic causes like gas poisoning).

We excluded events that might have resulted in an HI with any normal mortal, but not Tintin. We only considered significant events revealed at least by symbols (candles, stars, squiggles) revolving around any part of Tintin's body (head, limbs or trunk). Where symbols surrounded two people, including Tintin, in a single frame, we only logged the incident if Tintin clearly appeared as a victim of the HI. We defined an LoC's duration by the number of elapsed frames before Tintin reverted to his usual appearance or behaviour.

For each HI we assessed: geographical location (distinguishing between Belgium, nontropical and tropical sites, and undetermined ones), cause (distinguishing intentional from unintentional events), and consequences (surgery, hospitalisation). Intentional HIs perpetrated by others included attempted homicide or assault, arrest, and events provoked by Tintin's friends (termed "friend-related"). Unintentional causes of HIs include environment-related events (animal exposure, natural disasters, extreme temperatures), transport accidents, events resulting from Tintin's acts, or following his lapses of judgement (termed "Tintin-related"), and other unintentional events. Each category included one to nine items.

We assessed the number of HIs per adventure, those occurring in Belgium and elsewhere, distinguishing between tropical, non-tropical, and undetermined countries. We summarised categorical variables using percentages, and made comparisons by using the Fisher exact test. We summarised continuous variables using means +/- standard deviations and compared using the Student test. 


\section{Results}

We found 244 HIs [mean 8.4/adventure (standard deviation +/- 5.8), median 8/adventure; range 1-30/adventure] and 13 kidnappings (Table I). Half the adventures were written between 1930 and 1945 (median =1944). There was at least one HI per adventure. The mean number of HIs per album was significantly higher before 1945 than afterwards $(14.9 \pm 7.1 \mathrm{v}$ $6.1 \pm 4.7 ; \mathrm{p} 0.002$ ). This was also true of the number of kidnappings ( $11 \mathrm{v} 2$, e.g. 1.0 per album \pm 0.7 v $0.09 \pm 0.3 ; \mathrm{p} 0.001$ ). Kidnapping was associated with HIs ten times, six resulting from traumatic attack and four from gas or chloroform poisoning. Three kidnappings were not associated with any HI (Table I).

Of the 244 HIs that occur in the 23 adventures, there were 191 traumas (78.3\%) and 53 nontraumatic problems $(21.7 \%)$. The most common forms of trauma were grade I and II concussion (47\%), BTwC (28\%) and grade III and IV concussion (16\%) (Table II). Overall there were 118 cases of concussion (112 concussion alone, and six associated with polytrauma) accounting for $48.4 \%$ of all HI. The other traumatic injuries included those caused by animals, burns, and gunshot wounds. The most common forms of non-traumatic problems were sleep problems $(15.1 \%)$, depression/anxiety (13\%), gas or chloroform poisoning (13\%), and alcohol-related problems (9.4\%) (Table III). We found 46 LoCs (28 grade III/IV concussions, one asphyxia related to strangulation by Captain Haddock, and 17 non-traumatic LoCs) (Table IV). However, the consequences of LoCs (the number of frames where Tintin was affected) could be evaluated in only 36 cases of LoC, with a mean of 9.5+/11 frames per involvement/LoC.

Despite leading such a dangerous life, Tintin was hospitalised only six times, including twice in one adventure (The Black Island). His stays ranged from one day in three adventures, to a few days or even weeks in three of his exploits. Hospitalisation twice follows gunshot wounds, and a car crash, fire, explosion and extra-terrestrial hypnosis once each. A car crash also brought a visit to casualty, which Tintin left without medical examination (King Ottokar's Sceptre).

Tintin twice underwent surgery after being shot (The Black Island, Destination Moon). Fortunately, the bullets merely grazed a rib or his skull. These two gunshots also caused an LoC. Tintin was also shot twice in the Land of the Soviets and in The Blue Lotus, but presents with nothing worse than a BTwC and a minor injury leading to shoulder immobilisation. There were 236 events since eight of the events resulted in two HIs. Of these 236 events, 69 (29\%) were intentional and 167 (71\%) were unintentional. The two most common events were homicide attempts, accounting for $80 \%$ of intentional causes and Tintin- related events 
representing $41.3 \%$ of unintentional causes. The other causal events by order of frequency were environment-related events, transport accidents, Tintin's friends' (mis) behaviour, and arrests (Table V). The most frequently-used weapon in attempted homicide or assault was a club or other object.

There were 33 transport accidents, including 27 unintentional accidents and six intentionallycaused accidents resulting from attempted homicide. The main means of transport involved in accidents were cars and aeroplanes. Of the 27 unintentional transport accidents, none occurred in Belgium; 24 happened in other countries (eight in tropical and 12 in non-tropical countries), and three en route.

The commonest environment-related events were animal exposure and natural disasters (avalanches, earthquakes, storms, Ocean waves), while extremes of temperature were less frequent (Table V). Of the seven injuries (bites, scratches) caused by animals, one scratch (condor) and two bites (lion, piranha) occurred in tropical countries, while two bites (by a rat and a shark) took place en route, one (by Snowy) on the meteorite and one (by a parrot) in Belgium. The eighth case of biting was inflicted by the boy Abdallah, so we classified the causal event as friend-related.

\section{Discussion}

This first snapshot of the 244 HIs in the 23 adventures reveals that HIs are common in Tintin's adventures, trauma accounting for $78 \%$ of $\mathrm{HI}$ and concussion for $48 \%$. But Tintin is highly resilient, being hospitalised a mere six times and undergoing surgery just twice.

We witnessed a sharp decline in HIs and a marked decrease of kidnappings in his stories after 1945. This deserves an explanation. From the outset, Tintin shares his adventures with his trusty canine companion, Snowy. However, the list of intrepid travellers progressively swells to include the buffoon detectives Thomson and Thompson in 1934, followed by the Chinese orphan Chang in 1936, the old sea dog Captain Haddock in 1941, and the scatter-brained Professor Calculus in 1944. Taken together, after 1945 this supporting cast progressively experiences numerous and diverse health impairments. We might justifiably wonder whether Hergé increasingly preferred to spare Tintin the burden of health problems, and instead allowed his new travelling companions to inherit his own place on the sick list. This decline may also be ascribable to a sense of war-weariness on Hergé's part. We know that Hergé's war-time stories were studiedly set in places far from Belgian shores obviating any possible controversy with the censors $[1,2]$. Could it be that his earlier pre-war depictions of violent acts and kidnapping, conceived in a climate of innocent playfulness, were no longer palatable 
to a man who had grown to understand the true consequences of the darker forces of human nature?

The most frequent HI was concussion ( $48 \%$ of all HIs). In the medical literature concussion is defined as mild traumatic brain injury, mild brain injury or mild head injury, which are all synonymous. Many systems measure the severity, or grade, of concussion but there is little agreement over the best $[6,7]$. We therefore used an "Hergé" grading system after considering the clinically evident post-traumatic signs (symbols surrounding Tintin's head after trauma): stars (grade I), whirls or candles (grade II), and LoCs (grades III and IV according to duration). This system is simple and overlaps with the two most widely-used systems for grading concussion [8]. Kamp and colleagues assessed the 704 traumatic head injuries in the 34 Astérix adventures, where the major cause of trauma was assault and where the traumas were severe in over $50 \%$ of head wounds. But there all the characters were scrutinised, not only the heroes [9].

LoCs were the severest HIs, and represent $18.8 \%$ of all HIs. They mostly related to severe (grade III and IV) concussions (60.9\% of LoCs), intoxication (13\%) or G-force injuries (8.7 $\%$ ) (Table IV). We reached a different total of LoCs than the Cyr family [3]; while they found 50 LoCs in 16 adventures, we detected 46 LoCs in 16 of the 23 adventures. We have reviewed all the frames where the Cyrs diagnosed LoCs [3] and disagree over the diagnosis of LoCs in 19 of their 50 cases. For instance, in 11 situations they described as LoCs, we instead classified the events as concussion grades I and II as they did not lead to LoCs. Our analysis also suggests the Cyrs missed some LoCs, for instance 3 non-traumatic LoCs in Cigars of the Pharaoh and three of the four LoCs related to G-force events travelling to or from the moon (two take-offs and two landings).

The commonest non-traumatic HIs were sleep disturbances (nightmares, insomnia), intoxication (gas, chloroform), and manifestations of anxiety or depression (tears), as highlighted in another study which focused solely on mental disorders in the characters who appear in Tintin adventures [4]. Sleep disturbances might reasonably be attributed to Tintin's highly stressful life. Tintin even bursts into tears when the lives of his dearest companions (Snowy and Chang) are in peril or when he is separated from them. Despite his super-human qualities, Tintin is also a 'regular guy', which unquestionably boosts his popularity [2]. There was no clear relationship between the type of $\mathrm{HI}$ and travel destination when we focused on tropical destinations alone. Tintin presents none of the commonest travel-related health impairments such as diarrhoea, respiratory tract infections, sunburn, insect bites or fever [10]. For instance, when travelling by boat he is not seasick although this is the 
commonest HI on ships [11]. When scaling the Himalayas or the Andes he never suffers altitude sickness although this is a common HI among travellers to Peru [12]. Although in Tintin's adventures transport accidents are non-fatal, road accidents are the leading cause of non-natural deaths suffered by travellers abroad and are more frequent than intentional injuries [13]. Southeast Asia produces the highest unintentional injury death rates for Americans abroad owing to the high death rate from motorbike accidents, especially in Thailand and Vietnam.

Some of the HIs resulted from exposure to animals, (bites, scratches, shaking, shocks, bumps, strangulation) primarily Snowy (who is presumably vaccinated against rabies), but also with a vast menagerie of non-canines (horses, lions, sharks, condors, electric rays, parrots, piranhas, rats and yaks). The outcome was a bite in six cases and scratches in one. Although the animals are not typical rabies carriers, travellers who lead quite such adventurous lives should certainly consider getting vaccinated prior to their travels [14].

We found five alcohol-related HIs in Tintin, including two in his first adventure and one in his final escapade. The first two relate to heavy drinking in Russia, and the last results from Professor Calculus's experimental anti-alcohol pill. This pill was intended to wean Captain Haddock off alcohol, but Tintin inadvertently swallows it and suffers its effects. Tintin's sometime profession of journalism entails risks such as kidnapping. This is truly an escalating concern as the number of journalists kidnapped more than doubled in 2013 [15]. Our hero is kidnapped no fewer than 13 times. He is taken hostage in just one adventure (Land of Black Gold) in the Middle East. No ransom is demanded and he is rescued four times by his faithful companion, Snowy. Perhaps thereafter Tintin becomes less vulnerable since he was kidnapped only once after 1950 (Table I). Could he have gained some wisdom with age? Tintin also presents HIs that result from aberrant behaviour by his closest companions. It is hard to escape the conclusion that they behave bizarrely because of significant underlying health problems [1, 2]. Captain Haddock is an alcoholic, Professor Calculus is stone deaf, and Thomson and Thompson are just plain stupid.

This study has some limitations. We may have missed some health events or kidnappings. The dividing line between a modest trauma and a significant trauma leading to a $\mathrm{HI}$ is sometimes narrow since Hergé also uses symbols to accentuate a narrative event. In some instances it was also hard to differentiate between a simple homicide and a kidnapping when the aim of the kidnapping was homicide. Also, none of the authors is a traumatologist. Finally Hergé's scenario are so rich in content that it was a challenge to classify some of the HIs. It was especially tough with events where there is strong interaction between Tintin, his friends, 
Snowy, means of transport, animal or natural disasters. We hope that our passion for Tintin

has nevertheless overcome most of these limitations.

In conclusion, Tintin is clearly an extraordinary character whose adventures continue to delight his many readers 85 years after his first appearance. Children and adults alike are enchanted by the globe-trotting adventures of a boy, his dog, and his eccentric companions. It remains for the sober physician to raise a horrified eyebrow at the characters' insouciant failure to prepare for their hazardous voyages or to manage their many ailments properly. Nevertheless, although a modicum of common sense might spare the characters most of their calamities, it's actually far more fun to delight in this superhuman spirit who guilelessly journeys abroad effortlessly overcome the many travel-related illnesses and traumatic events we mere mortals face daily.

\section{Conflict of interest: none}

\section{References}

1- Wikipedia. The Adventures of Tintin. www.en.wikipedia.org/wiki/The_Adventures_of_Tintin. Accessed on August 15, 2014

2- Tout savoir sur Tintin. www.ydeb.free.fr/Tintin_fichiers/tintin/tintin.htm.Accessed on August 15, 2014

3- Cyr A, Cyr LO, Cyr C. Acquired growth hormone deficiency and hypogonadotropic hypogonadism in a subject with repeated head trauma, or Tintin goes to the neurologist. CMAJ 2004;171:1433-4.

4- Medrano J, Malo P, Uriarte JJ, López AP. Stigma and prejudice in Tintin. BMJ. 2009;339. b5308

5- Castillo M. Tintin and colleagues go to the doctor. AJNR Am J Neuroradiol 2011;32:19756

6- Terrell TR, Cox CB, Bielak K, Casmus R, Laskowitz D, Nichols G.

Sports Concussion Management: part II. South Med J. 2014;107:126-35.

7- Terrell TR, Nobles T, Rader B, Bielak K, Asif I, Casmus R, Yeager J, Hussein R.

Sports concussion management: part I. South Med J. 2014;107:115-25.

8- Chan V, Thurairajah P, Colantonio A1. Defining traumatic brain injury in children and youth using international classification of diseases version 10 codes: a systematic review protocol. Syst Rev. 2013;2:102.

9- Kamp MA, Slotty P, Sarikaya-Seiwert S, Steiger HJ, Hänggi D. Traumatic brain injuries in illustrated literature: experience from a series of over 700 head injuries in the Asterix comic books. Acta Neurochir 2011;153:1351-5;

10- Hill DR. Health problems in a large cohort of Americans traveling to developing countries. J Travel Med. 2000;7:259-66.

11- Shaw MT, Harding E, Leggat PA. Illness and injury to students on a school excursion to Peru. J Travel Med. 2014;21:183-8. 12- Schutz L, Zak D, Holmes JF. Pattern of passenger injury and illness on expedition cruise ships to Antarctica. J Travel Med. 2014;21:228-34. 
13- Sherry MK, Mossallam M, Mulligan M, Hyder AA, Bishai D. Rates of intentionally caused and road crash deaths of US citizens abroad. Inj Prev. 201. doi: 10.1136/injuryprev2013-040923.

14- Gautret P, Schwartz E, Shaw M, Soula G, Gazin P, Delmont J, Parola P, Soavi MJ, Matchett E, Brown G, Torresi J. Animal-associated injuries and related diseases among returned travellers: A review of the GeoSentinel Surveillance Network. GeoSentinel Surveillance Network. Vaccine 2007;25:2656-63.

15- Taylor G. Number of Journalists kidnapped more than doubled in 2013: report. The Washington Times, 2013. December 18. Available on http://www.washingtontimes.com/news/2013/dec/18/number-journalists-kidnapped-moredoubled-2013

\section{Legends for the figures:}

Figure 1: This is an advertisement in Brussels (Belgium) showing Tintin riding a motorbike in the King Ottokar's Sceptre.Credit: Eric Caumes

Figure 2: This is a painted wall in the Brussels main train station showing Tintin driving a rail locomotive in Tintin in America. Credit : Eric Caumes 
Table I: Tropical and non-tropical destinations visited by Tintin during his $\mathbf{2 3}$ adventures, health impairments and kidnappings per adventure 


\begin{tabular}{|c|c|c|c|c|c|c|c|}
\hline Album name & Year & $\begin{array}{l}\text { Belg } \\
\text { ium }\end{array}$ & $\begin{array}{l}\text { Non-tropical } \\
\text { countries }\end{array}$ & $\begin{array}{l}\text { Tropical } \\
\text { countries }\end{array}$ & $\begin{array}{l}\text { Undetermined } \\
\text { countries }\end{array}$ & $H I()^{\star}$ & Kid \\
\hline $\begin{array}{l}\text { Land of } \\
\text { Soviets }\end{array}$ & 1930 & No & $\begin{array}{l}\text { Germany } \\
\text { Russia }\end{array}$ & & & $\begin{array}{l}30 \\
(1)^{*}\end{array}$ & 1 \\
\hline Congo & 1931 & No & & Congo & & 15 & 0 \\
\hline America & 1932 & No & USA & & & 14 & $3^{\star \star}$ \\
\hline $\begin{array}{l}\text { Cigars of } \\
\text { Pharaoh }\end{array}$ & 1934 & No & & $\begin{array}{l}\text { Egypt, Arabia, } \\
\text { India }\end{array}$ & & 15 & $2 \star \star$ \\
\hline Blue Lotus & 1936 & No & China & India & & 13 & 1 \\
\hline Broken Ear & 1937 & Yes & & $\begin{array}{l}\text { San Theodoros, } \\
\text { Nuevo Rico }\end{array}$ & & $16(2)^{*}$ & 2 \\
\hline Black Island & 1938 & Yes & $\begin{array}{l}\text { United } \\
\text { Kingdom }\end{array}$ & & & $21(1)^{*}$ & \\
\hline King Ottokar & 1939 & Yes & $\begin{array}{l}\text { Syldavia, } \\
\text { Borduria }\end{array}$ & & & 16 & \\
\hline $\begin{array}{l}\text { Crab with } \\
\text { Golden Claws }\end{array}$ & 1941 & Yes & & Morocco & & 13 & 1 \\
\hline Shooting Star & 1942 & Yes & Iceland & & Meteorite & 19 & \\
\hline $\begin{array}{l}\text { Secret of } \\
\text { Unicorn }\end{array}$ & 1943 & Yes & & & & 5 & 1 \\
\hline $\begin{array}{l}\text { Red Rackham's } \\
\text { Treasure }\end{array}$ & 1944 & Yes & & Caribbean & & 2 & \\
\hline Crystal Balls & 1948 & Yes & France & & & 4 & \\
\hline $\begin{array}{l}\text { Prisoners of } \\
\text { Sun }\end{array}$ & 1949 & No & & Peru & & 6 & \\
\hline $\begin{array}{l}\text { Land of Black } \\
\text { Gold }\end{array}$ & 1950 & Yes & & Khemed & & 18 & 1 \\
\hline $\begin{array}{l}\text { Destination } \\
\text { Moon }\end{array}$ & 1953 & Yes & Syldavia & & Space & $4(1)^{*}$ & \\
\hline $\begin{array}{l}\text { Explorers on } \\
\text { the Moon }\end{array}$ & 1954 & No & & & Space and moon & 8 & \\
\hline $\begin{array}{l}\text { Calculus } \\
\text { Affair }\end{array}$ & 1956 & Yes & $\begin{array}{l}\text { Switzerland, } \\
\text { Borduria }\end{array}$ & & & $8(2)^{*}$ & \\
\hline $\begin{array}{l}\text { Red Sea } \\
\text { Sharks }\end{array}$ & 1958 & Yes & & Khemed & & 3 & \\
\hline Tibet & 1960 & No & $\begin{array}{l}\text { France, } \\
\text { Nepal, Tibet }\end{array}$ & India & & $8(1)^{*}$ & \\
\hline $\begin{array}{l}\text { Castafiore } \\
\text { Emeralds }\end{array}$ & 1963 & Yes & & & & 2 & \\
\hline Flight 714 & 1968 & No & & Indonesia & & 3 & $1^{\star \star}$ \\
\hline Picaros & 1976 & No & & San Theodoros & & 1 & \\
\hline$N=$ & & 31 & 115 & 81 & 17 & 244 & 13 \\
\hline
\end{tabular}

BTWC: Body Trauma without consequences

$\mathrm{N}=$ Number of health impairments and kidnappings.

$\mathrm{HI}=$ Health impairments

Kid = kidnappings

*: Adventures in which one event (1) or two events (2) led to two health impairments **: Including one kidnapping without health impairment 
Table II: Traumatic health impairments suffered by Tintin

\begin{tabular}{llr}
\hline Concussion alone & Grade I and II & 84 \\
& Grade III & 2 \\
& Grade IV & 24 \\
& Grade III /IV & 2 \\
& Total Concussion alone & $\mathbf{1 1 2}$ \\
\hline Polytrauma* & & $\mathbf{6}$ \\
\hline BTWC & Back & \\
& Bottom** & 8 \\
& Foot & 16 \\
& Upper limbs & 4 \\
& Neck & 12 \\
& Shoulder & 5 \\
& Trunk & 2 \\
& Total BTWC & 6 \\
& & $\mathbf{5 3}$ \\
\hline Burns & & $\mathbf{6}$ \\
Gunshot injury*** & & $\mathbf{3}$ \\
Bite**** & & $\mathbf{7}$ \\
Miscellaneous****** & & $\mathbf{4}$ \\
\hline Total & & $\mathbf{1 9 1}$ \\
\hline
\end{tabular}

BTWC: Body Trauma without consequences

* All polytrauma were associated with concussion grade I $(n=4)$ or Grade II $(n=2)$ giving a total of 118 concussions

** Including one related to gunshot

*** Including three injuries (shoulder, skull and rib) in association with LoC in two cases

**** Bites by dog (Snowy), human (Abdallah), lion, parrot, piranha, rat, shark (one each)

***** Including scratches (condor), bumps, ankle twisting and strangulation 
Table III: Non-traumatic health impairments suffered by Tintin

Non-traumatic health impairment,

Sleep problems * $\quad 8$

Intoxication** $\quad 7$

Depression/anxiety (tears)*** $\quad 7$

Alcohol 5

G-Force 4

Lack of oxygen $\quad 3$

Cold-related $\quad 3$

Profound asthenia $\quad 2$

Heat stroke $\quad 2$

Near-drowning $\quad 2$

Amnesia $\quad 2$

Coryza 2

View troubles $\quad 2$

Miscellaneous**** 24

TOTAL $\quad 53$

* Including five nightmare, and three insomnia

** Including three toxic gas, and four chloroform-inhalation,

*** Linked to Chang $(\mathrm{n}=4)$ or Snowy $(\mathrm{n}=2)$ disappearance, and singing Bianca Castafiore

**** Including psychotic access, high stress, hypoglycaemia, and CO-inhalation (one each) 
Table IV: Causal events and health impairments (HI) associated with loss of consciousness (LoC) in the 23 adventures of Tintin

\begin{tabular}{|c|c|c|c|}
\hline & Causal event (page) & HI associated to LoC & LoC \\
\hline $\begin{array}{l}\text { Land of } \\
\text { Soviets }\end{array}$ & $\begin{array}{l}\text { Hit by club (104) } \\
\text { Punched KO (119) }\end{array}$ & $\begin{array}{l}\text { Concussion grade IV } \\
\text { Concussion grade IV }\end{array}$ & 2 \\
\hline Congo & $\begin{array}{l}\text { Fight with lion (22) } \\
\text { Hit by stick (32) } \\
\text { Hit by block of wood (43) }\end{array}$ & $\begin{array}{l}\text { Concussion grade IV } \\
\text { Concussion grade IV } \\
\text { Concussion grade IV }\end{array}$ & 3 \\
\hline America & $\begin{array}{l}\text { Car accident (4) } \\
\text { Hit by stick (5) } \\
\text { Toxic gas poisoning (12) }\end{array}$ & $\begin{array}{l}\text { Concussion grade IV } \\
\text { Concussion grade IV } \\
\text { NT LoC }\end{array}$ & 3 \\
\hline $\begin{array}{l}\text { Cigars of } \\
\text { Pharaoh }\end{array}$ & $\begin{array}{l}\text { Toxic gas poisoning }(9) \\
\text { Near-drowning }(12) \\
\text { Near-drowning }(21)\end{array}$ & $\begin{array}{l}\text { NTLoC } \\
\text { NT LoC } \\
\text { NT LoC } \\
\end{array}$ & 3 \\
\hline Blue Lotus & Chloroform poisoning (15) & NTLoC & 1 \\
\hline Broken Ear & $\begin{array}{l}\text { Hit by club (25) } \\
\text { Shooting in car }(42) \\
\text { Blow from oar }(55)\end{array}$ & $\begin{array}{l}\text { Concussion grade IV } \\
\text { Concussion grade IV } \\
\text { Concussion grade IV }\end{array}$ & 3 \\
\hline Black Island & $\begin{array}{l}\text { Gunshot (1) } \\
\text { Blow from club (7) } \\
\text { Intoxication (18) } \\
\text { Asphyxia by smoke/CO (22) } \\
\text { Bump into rake (26) } \\
\text { Impact with stone }(52) \\
\end{array}$ & $\begin{array}{l}\text { Concussion grade III/IV } \\
\text { Concussion grade IV } \\
\text { NTLoC } \\
\text { NTLoC } \\
\text { Concussion grade IV } \\
\text { Concussion grade IV } \\
\end{array}$ & 6 \\
\hline $\begin{array}{l}\text { Ottokar 's } \\
\text { Sceptre }\end{array}$ & $\begin{array}{l}\text { Accident: prison van (39) } \\
\text { Hit by camera cord (45) } \\
\text { Hit by wooden stick (48) }\end{array}$ & $\begin{array}{l}\text { Concussion grade IV } \\
\text { Concussion grade III } \\
\text { Concussion grade IV } \\
\end{array}$ & 3 \\
\hline $\begin{array}{l}\text { Crab with } \\
\text { Golden } \\
\text { Claws }\end{array}$ & $\begin{array}{l}\text { Blow from club (10) } \\
\text { Hit by whisky bottle }(25) \\
\text { Blow from bone }(30) \\
\text { Strangulation by Haddock (30) } \\
\text { Heat exhaustion (32) }\end{array}$ & $\begin{array}{l}\text { Concussion grade III/IV } \\
\text { Concussion Grade III } \\
\text { Concussion grade III } \\
\text { Asphyxia } \\
\text { NT LoC }\end{array}$ & 5 \\
\hline $\begin{array}{l}\text { Shooting } \\
\text { Star }\end{array}$ & Hit by giant apple (56) & Concussion grade IV & 1 \\
\hline $\begin{array}{l}\text { Secret of } \\
\text { Unicorn }\end{array}$ & Chloroform intoxication (35) & NTLoC & 1 \\
\hline $\begin{array}{l}\text { Land of } \\
\text { Black Gold }\end{array}$ & $\begin{array}{l}\text { Gas inhalation (16) } \\
\text { Heat stroke }(21) \\
\text { Blow from stick (27) }\end{array}$ & $\begin{array}{l}\text { NT LoC } \\
\text { NTLoC } \\
\text { Concussion grade IV }\end{array}$ & 3 \\
\hline $\begin{array}{l}\text { Destination } \\
\text { Moon }\end{array}$ & $\begin{array}{l}\text { Gunshot (21) } \\
\text { G Force take-off (59) }\end{array}$ & $\begin{array}{l}\text { Concussion grade IV } \\
\text { NTLoC }\end{array}$ & 2 \\
\hline $\begin{array}{l}\text { Explorers on } \\
\text { Moon }\end{array}$ & $\begin{array}{l}\text { G force landing (22) } \\
\text { Hit by club (39) } \\
\text { G Force taking off (51) } \\
\text { Hypoxemia (53) } \\
\text { G Force landing (57) } \\
\text { Lack of oxygen (57) }\end{array}$ & $\begin{array}{l}\text { NTLoC } \\
\text { Concussion grade IV } \\
\text { NTLoC } \\
\text { NTLoC } \\
\text { NTLoC } \\
\text { NTLoC }\end{array}$ & 6 \\
\hline $\begin{array}{l}\text { Calculus } \\
\text { Affair }\end{array}$ & $\begin{array}{l}\text { House explosion (27) } \\
\text { Blow from club (30) }\end{array}$ & $\begin{array}{l}\text { Concussion grade IV } \\
\text { Concussion grade IV }\end{array}$ & 2 \\
\hline Tibet & $\begin{array}{l}\text { Fall into crevasse (31) } \\
\text { Avalanche }(44)\end{array}$ & $\begin{array}{l}\text { Concussion grade IV } \\
\text { Concussion grade IV }\end{array}$ & 2 \\
\hline Total & & & 46 \\
\hline
\end{tabular}

HI: Health impairments; LoC: loss of consciousness; NTLoC: non-traumatic loss of consciousness 
Table V: 236 events leading to 244 health impairments suffered by Tintin

\begin{tabular}{llr} 
Event categories & Event details & Total \\
\hline Intentional & Homicide attempts* & 55 \\
& Arrest & 7 \\
& Friend related & 5 \\
Total intentional & Tintin related & 2 \\
\hline Unintentional & & $\mathbf{6 9}$ \\
\hline & Tintin-related** \\
& Environmental*** & 69 \\
& Transport accidents & 32 \\
& Other unintentional events & 27 \\
& Friend-related & 28 \\
Total Unintentional & & 11
\end{tabular}

* Including six intentionally-caused transport accidents $($ car $=2$; Motor track $=1$; motorbike $=1$; parachute = 1 , as pedestrian $=1$ )

** Including 27 falling on something or someone, 21 medical problems (sleep problems, depression/anxiety, asthenia, ...) 15 bumping into someone or into something, and five other events

$* * *$ Including 11 natural disasters (avalanche $=2$; sandstorm $=3$; earthquake $=3$; lightning $=1$; petrol jet $=1$; storm $=1$ ), 14 animal exposure (horse $=3$; lion $=2$; shark $=2 ;$ bear $=1$; condor $=1$; electric ray $=1 ;$ hippo $=1$; parrot $=1$; piranha $=1$; rat $=1$; yak $=1), 5$ extreme temperatures $($ cold $=3$, heat $=2)$ and two other environmental events 


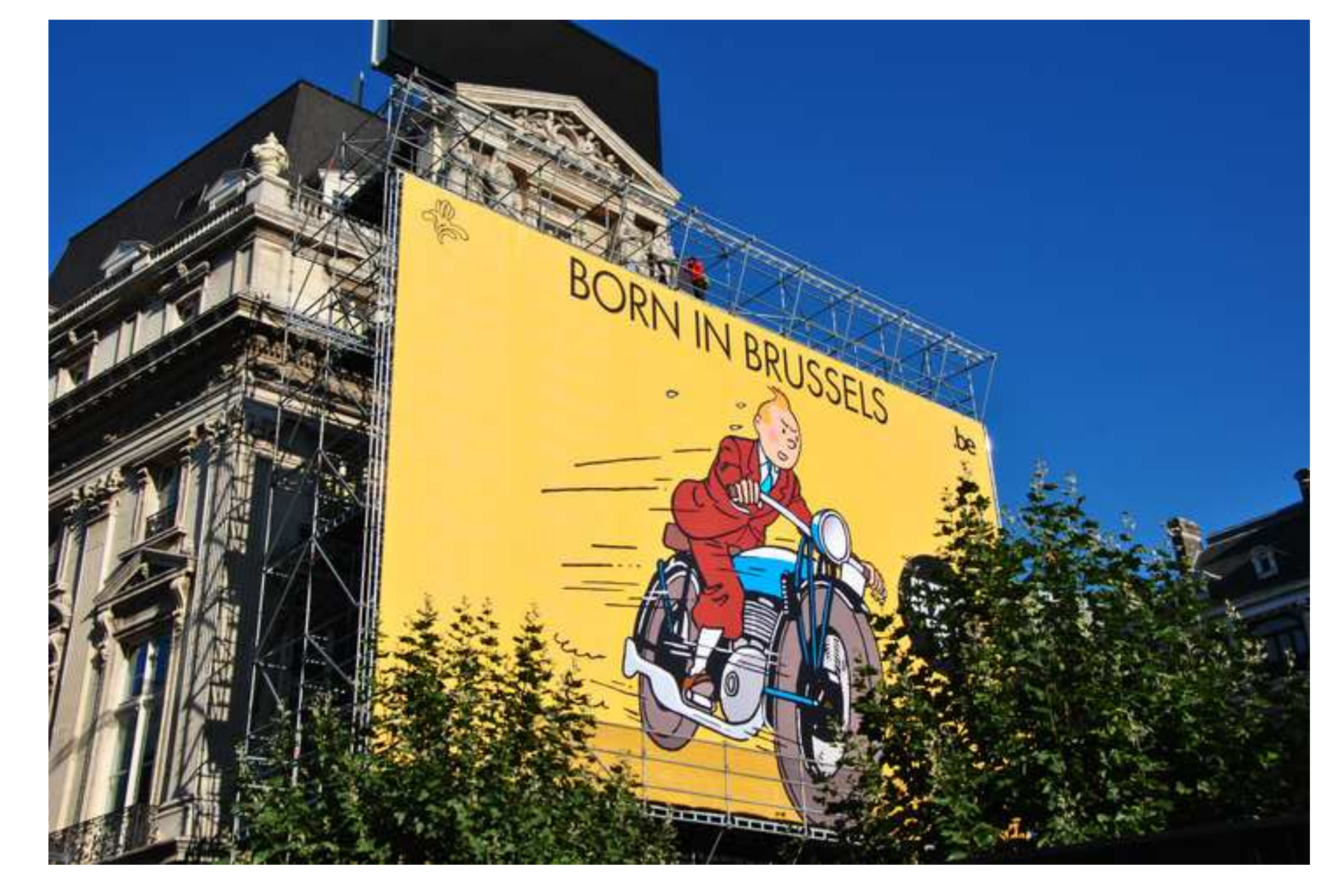

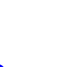

Click here to download high resolution image

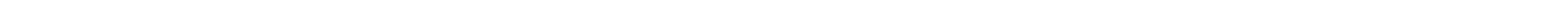

要 
Figure
Click here to download high resolution image

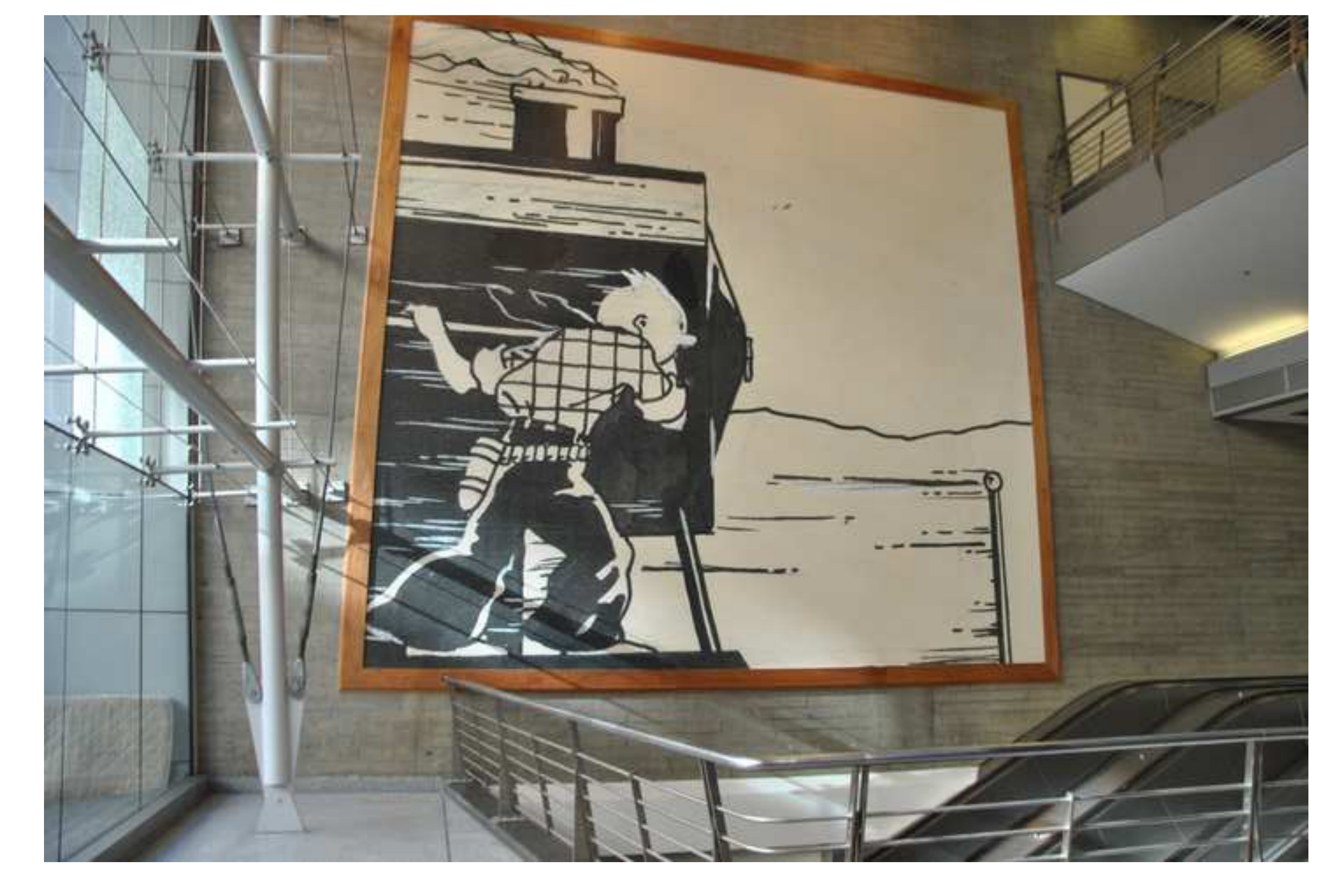

Click here to download high resolution image (1)

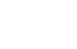
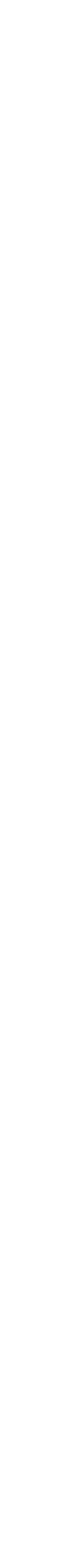